Volume 8, No.1.5, 2019

International Journal of Advanced Trends in Computer Science and Engineering

Available Online at http://www.warse.org/IJATCSE/static/pdf/file/ijatcse4181.52019.pdf

https://doi.org/10.30534/ijatcse/2019/4181.52019

\title{
The Role of Attitude in Mediating the Effect of perceived usefulness on the intention to use E-Money
}

\author{
Ni Nyoman Sudiyani, Ni Putu Yuliana Ria Sawitri², Ade Maharini Adiandari ${ }^{3}$, \\ Luh Putu Virra Indah Perdanawati ${ }^{4}$ \\ ${ }^{1}$ Ngurah Rai University, Indonesia, nyoman.sudiyani@unr.ac.id \\ ${ }^{2}$ Ngurah Rai University, Indonesia, yulianariasawitri@yahoo.om \\ ${ }^{3}$ Ngurah Rai University, Indonesia, maharini.adiandari@unr.ac.id \\ ${ }^{4}$ Ngurah Rai University, Indonesia, virra.indah@unr.ac.id
}

\begin{abstract}
This examination means to decide how the impacts of perceived usefulness and attitude toward one's intention to using e-money in Denpasar. The area for this exploration held in Denpasar. The quantity of tests taken is 100 individuals, with a likelihood inspecting methods are basic irregular examining. Information examination in this investigation utilized the Partial Least Square (PLS) approach. PLS is a condition model for Structural Equation Modeling (SEM) in view of parts or variations. This examination is to get results which expressed that the of perceived usefulness has a constructive impact and significant additionally somewhat on a person intentions and attitude toward intention to use e-money in Denpasar. There was a noteworthy constructive outcome and impact attitude towards one's intention to use e-money in Denpasar. Found likewise the intention to use e-money in Denpasar can be impacted by of perceived usefulness and attitude mostly as an mediating variable.
\end{abstract}

Key words: perceived usefulness, attitude, intention to use

\section{INTRODUCTION}

Cash as a techniques for bit is the progression of plan create. Cash as "whatever is Generally Accepted in bit for item and adventures or in the reimbursement of duties". At the start, the cash can be as contacts, shells, or metal. Beginning in the generally later past, cash may merges banknotes, coins, checks or move structure [1].

A piece of the parts of cash by [1], to be express: First, cash as a vehicle of trade. Cash as a technique for trade is head specialization and development in passing on a thing, in light of the path that with the cash that individuals don't need to swap that item made in the market and with the cash he earned from its breathing space is spent or obtained the things needs. Second, cash as a unit of record. With this breaking point, the estimation of a thing can be evaluated and in the relationship. Third, cash as a store of significant worth. The points of confinement related with human sense as pros of riches. Fourth, cash as an instrument for future parts. With no other person's data the estimation of which is settled dependent on the budgetary standard conviction, this exhibits the estimation of the rupiah isn't ensured by certain stunning metals (gold) yet set by government through Bank Indonesia. This is in light of the way that Bank Indonesia is an establishment that has the decision to print and stream rupiah as cash.

The advancement in business trade ends up being new development that unequivocally impacts on associations exercises [2]. In business trade, it is critical when it incorporate mechanized advancement since its effect to the system in banking exchange [3]. This transforms into an annoyed to empowered electronic trade as new sorts of instruments portions that the customers can use by getting the information and correspondence of the framework [4].

In its improvement, moving towards the part instrument and electronic cards, for instance Visas, ATM/charge, and e-money. E-money is seeded into a procedures for segment made game plans for exchanges of insignificant worth. Different appraisals have displayed the upsides of utilizing e-cash as most absurd adaptability in bit exchanges insignificant clear entirety. For instance, in vehicle, in films, clubs, and the segment of fines, charges and court orders. It is certainly not difficult to make estimations on the web when purchasing standard and electronic things, for example, the acquisition of PC programming and the other [5].

E-money partition technique ought to be possible rapidly and there is no run of the mill issue, for example, lines. E-cash is moved from the payer to the beneficiary inside seconds. E-cash have fundamental positive conditions separated and money, yet it has additionally hindrances. National banks in different nations are worried over the improvement of e-money, particularly on the issuance (discharge) e-cash that are not controlled and the risk of encroachment appearing [6].

Shows that e-money can give a wide degree of valuable outcomes, for example, solace and confirmation, the decrease in costs related, potential new business, likewise as the exchanging of money related exercises among frameworks on the Internet [7]. In any case, there are crude issues that ascent concerning the presentation of e-money. Foundation of electronic cash raises various issues identifying with evaluate amassing and charges of unlawful cost avoidance. In like way, 
the worry over secret and the likelihood of spillage of individual information of occupant.

E-money antagonistically impacts the enormous scale economy, for example, swapping scale unpredictability and the nonappearance of attestations for true money [8]. Nonappearance of security genuine cash showed up due to the charges at one point, the extent of virtual cash will no uncertainty beat the extent of genuine cash.

Issues related with the utilization of e-cash may also occur because of liquidity issues promoter (guarantor) them, likewise as the eventual outcomes of the obligations compelled by the supporter. Conferred worries over security and purchaser affirmation is a significant issue in the utilization of e-money, for example, if there should rise an occasion of hardship or burglary of the e-cash. E-money can be effectively utilized by different social gatherings who are not answerable for unapproved e-money as a Personal Identification Number (PIN) or engraving, for example, MasterCard and ATM card/debit [9].

Dismissing the way that the use of e-money will increment later on, yet the framework without $100 \%$ money would not have been conceivable. E-cash gives more crucial comfort and more dominant than money part structure, there are several components that don't bolster the loss of money partition framework, for instance: First, the cost required to manufacture a course of action of PCs, card scrutinizes, and the essential systems to make e-cash to be the general kind of bit would be very expensive. Second, electronic part instruments to empower an all-inclusive risk of security and protection contemplations. This is displayed by the likelihood of exchange of focal points starting with one record then onto the accompanying unlawfully. In like manner, the pressure is that associations, boss, or e-money suppliers can get to the individual information of clients that aggravates the portrayal of individual data [10].

A piece of the sections that incline an individual to utilize or not to utilize e-cash are the dangers and seen success that would then have the choice to affect the client's discernment when all is said in done fiscal exercises, exercises of e-banking, e-bit and online part by [11] [12] and found that the fundamental factor influencing the lead of the client social occasion of e-cash is the chief seen bit of breathing space of clients. While the dangers and security considerations don't diminish or affect buyer expect to get a handle on e-money [13].

That apparent value positively affects conduct expectations to utilize portable banking in Malaysia [14]. Singular goals can be affected on apparent handiness their found by [15] [16]. There is a significant positive connection between saw value and goal to utilize web based banking in North America [17]. The aim to utilize web banking in Malaysia, in light of the fact that perceived usefulness has a positive and noteworthy relationship to intention [18].

There is likewise a significant relationship between perceived usefulness and intention to use technology [19]. There was a positive impact between perceived usefulness on one's intention to use web banking their found by [20] [21]. In any case, it is unique in relation to the exploration led by [22] states that perceived usefulness doesn't influence conduct intention to use m-banking.

Purchaser recognition significantly impacts how buyers demeanors towards an item. That perceived usefulness positively affects attitude towards using mobile banking their discovered by [14] [23]. That e-government frameworks will improve client execution and efficiency bolstered by a huge impact between perceived usefulness on attitudes [24]. Besides discovered outcomes that perceived usefulness positively affected an person attitude in using mobile banking and web banking [25].

There is a positive impact between attitude factors on intention to use mobile banking in Malaysia [14]. Attitude impacts on intention to use mobile phones/services [24]. There is a critical positive connection between attitude toward and intention to use internet banking in North America [17]. Besides the exploration of states that there is a noteworthy direct impact between attitude towards intention to use web banking [26]. That attitude towards the intention to use of portable banking, intercede the connection between perceived usefulness and behavioral intention to use mobile banking in Malaysia [14]. Moreover with the exploration of [27] states that perceived usefulness has a positive association with the intention to use m-banking interceded by attitude towards m-banking. Attitude has immediate and backhanded impacts between perceived usefulness and intention to use e-marketing [28].

\section{LITERATURE REVIEW AND HYPOTHESES}

Perceived usefulness can be explained, namely the extent to which a particular system can improve one's performance [29]. The term interest is the terminology of the personality aspect to describe the existence of the will, the impulse (force) arising from within the individual to choose other similar objects. perceived usefulness can be measured by several indicators namely, faster, more accurate, increasing effectiveness, increasing performance, productivity, and useful [30]. Consumer intentions can be impacted by perceived usefulness, this announcement is fortified by [14] that perceived usefulness positively affects conduct intention to use mobile banking in Malaysia. There was a noteworthy effect on one's perceived usefulness towards the intention to use complex cell phone services [31]. Individual intention be affected by perceived usefulness their discovered by [15] [16]. Perceived usefulness and intention to use internet banking there is a noteworthy positive relationship in North America [17]. The intention to use web banking in Malaysia, on the grounds that perceived usefulness has a positive and furthermore noteworthy relationship to intention [18]. Moreover by [19] states that there is likewise a huge connection between perceived usefulness and intention to use innovation. There is a positive impact between perceived usefulness on one's intention to use web banking their discovered by [20] [21]. In light of this portrayal, the accompanying speculation is proposed: 
Ni Nyoman Sudiyani et al., International Journal of Advanced Trends in Computer Science and Engineering, 8(1.5), 2019,227 - 233

\section{H1: Perceived usefulness affects the intention to use}

Consumer attitudes can be affected by perceived usefulness, that perceived usefulness emphatically influences dispositions towards using convenient banking their states by [14] [23]. That e-government systems will improve customer execution and productivity supported by a gigantic effect between perceived usefulness on attitudes [30]. The results that perceived usefulness emphatically influenced a person's attitudein the use of flexible banking and web banking [25].

In perspective on the depiction, the going with theories are proposed:

\section{H2: Perceived usefulness affects the attitude of customers} Consumer intentions can be impacted by attitude, the states of [14] that there is a positive impact among attitude and behavioral intention to utilize versatile banking in Malaysia. Frame of mind impacts expectation to utilize cell phones/services [24]. There is a noteworthy positive connection between attitude toward using and intention to use web based banking in North America [17]. The conditions of [26] that utilizing web banking there is a significant direct impact on the attitude variable. In light of this depiction, the accompanying speculation is proposed:

\section{H3: customer attitudes influence the intention to use}

Coatumer intentions can be impacted by perceived usefulness with frames of mind as intervening practices, this announcement is strengthened by [14] that states attitude towards utilizing portable banking, interceding the connection between perceived usefulness and behavioral intentions to utilize versatile banking in Malaysia. In like manner with the examination of [27] states that perceived usefulness has a positive association with the aim to utilize $\mathrm{m}$-banking intervened by attitude towards m-banking. Besides, explore by [28] demonstrates that frame of mind has an immediate and roundabout impact between perceived usefulness and intentions to use e-marketing. In view of this portrayal, it is proposed speculation as pursues:

H4: the costumer's attitude intervenes the impact of perceived usefulness on the intention to use

From the clarification above, it very well may be schematically depicted as on the image beneath:

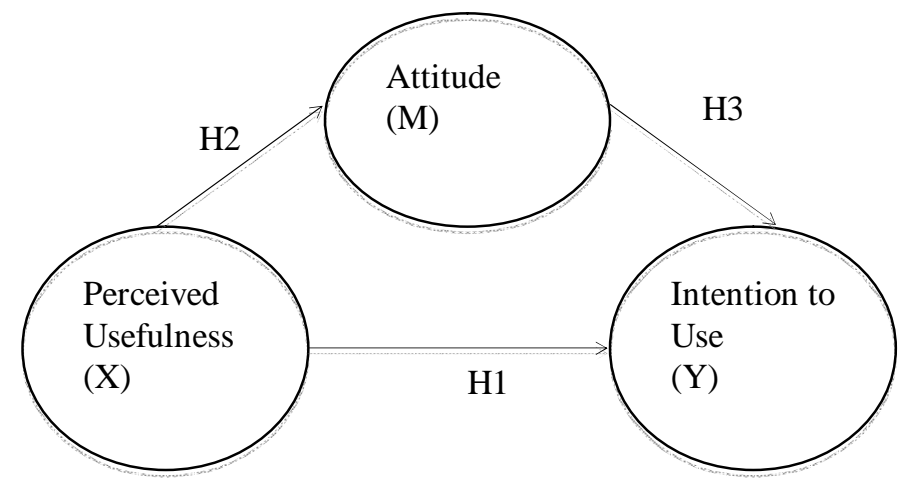

Figure 1: Research Framework

\section{RESEARCH METHODOLOGY}

The study of the role of attitude in mediating the relationship of perceived usefulness with the intention to use e-money was carried out in Denpasar with the consideration that the largest population is in the city of Denpasar. ests taken dependent on likelihood inspecting strategies are basic arbitrary examining, where specialists give equivalent chances to every individual from the populace to be picked as tests arbitrarily paying little respect to the strata in the populace itself with an absolute example of 100 respondents.

The estimation scale utilized in this investigation is the Likert scale, which is a scale that has been generally used to solicit respondents to stamp the degree from endorsement or conflict with a progression of improvement objects. The Likert scale utilized is 1 to firmly differ to 5 unequivocally concur. Information investigation in this examination utilized the Partial Least Square (PLS) approach. PLS is a condition model for Structural Equation Modeling (SEM) in view of segments or variations. To compliment the hypothesis and produce a down to earth model, this examination uses Structural Equation Modeling (SEM) with vacillation based or section based procedure with Partial Least Square (PLS). In case the basic model to be broke down meets the recursive model and the idle variable has regularizing markers. Intelligent or blended, the most appropriate approach to manage use is PLS. Before directing a test with the SEM-PLS strategy, this model is first tried by legitimacy . and unwavering quality. States that the authenticity test is used to evaluate the authenticity or authenticity of a survey. A survey is said to be generous if the request in the study can express something that will be assessed by the survey. A test can be said to have high authenticity if the test does its evaluating limit, or gives careful and exact estimation results according to the inspiration driving the test. A test produces data that isn't imperative to the explanation behind holding an estimation said to be a test that has low authenticity. Test the legitimacy of the instrument in this examination utilizing item minute relationship with a cut-off $\geq 0.30$ [32]. The instrument to be legitimate on the off chance that it has a relationship coefficient among the grain scale and the complete score in the instrument is more noteworthy than $0.30(r \geq 0.30)$. Unwavering quality test expects to discover to what degree the consistency of the estimating instrument utilized, so when the estimating instrument is utilized again to look at a similar article with a similar method despite the fact that the time is unique in relation to the outcomes to be acquired are the equivalent. To test the unwavering quality level utilizing Cronbach's coefficient productive alpha shows how far the things in the investigation are decidedly 
Ni Nyoman Sudiyani et al., International Journal of Advanced Trends in Computer Science and Engineering, 8(1.5), 2019,227 - 233

associated with one another. Dependability alludes to the estimation of cronbach's alpha with a cut off $\geq 0.60$ [32].

\section{FINDINGS}

\subsection{Validity Test}

\subsection{R-Square Test}

The R-square in this examination was utilized to gauge the develop of the reliant factors, while the parameters of every factor were tried utilizing the $t$ test and furthermore observed the importance estimations of every parameter. This is done to assess the model of auxiliary way parameters.

Table 1: Validity test

\begin{tabular}{llll}
\hline & Attitude & $\begin{array}{l}\text { Intention to } \\
\text { Use }\end{array}$ & $\begin{array}{l}\text { Perceived } \\
\text { Usefulness } \\
\text { X1.1 }\end{array}$ \\
X1.2 & & & 0.929 \\
X1.3 & & & 0.792 \\
X1.4 & & & 0.890 \\
X1.5 & & & 0.940 \\
M1.1 & $\mathbf{0 . 9 0 3}$ & & 0.817 \\
M1.2 & 0.779 & & \\
M1.3 & 0.891 & & \\
M1.4 & $\mathbf{0 . 7 6 7}$ & & \\
M1.5 & $\mathbf{0 . 8 3 2}$ & 0.971 & \\
Y1.1 & & 0.935 & \\
Y1.2 & & 0.940 & \\
Y1.3 & & & \\
\hline
\end{tabular}

Source: Data Processed (2019)

The table 1 above demonstrates that the aftereffects of perceived usefulness, attitude and intention to utilize inquire about markers have an external stacking estimation of more than 0.5 . The uncertainty pointer of the intention to use is the most grounded proportion of execution factors since it has the most elevated external stacking an incentive with an estimation of 0.971. Since all markers have an external stacking estimation of more than 0.5 , it very well may be presumed that there are three pointers that are legitimate pointers to quantify the aim to utilize.

\subsection{Reliability Test}

Reliability test intends to discover to what degree the consistency of the estimating instrument utilized so when the estimating instrument is utilized again to look at a similar item with a similar procedure despite the fact that the time is not the same as the outcomes to be acquired are the equivalent. To test the unwavering quality level utilizing Cronbach's coefficient productive alpha shows how far the things in the investigation are decidedly connected with one another. Unwavering quality alludes to the estimation of cronbach's alpha with a cut off $\geq 0.60^{32}$. Testing the reability test in this examination s as appeared in table 2 beneath.

Table 2: Reliability test

\begin{tabular}{llll}
\hline No & Variable & $\begin{array}{l}\text { Cronbach } \\
\text { Alpha }\end{array}$ & Results \\
& & $\mathbf{0 . 8 9 1}$ & Reliabel \\
1 & Attitude & $\mathbf{0 . 9 4 4}$ & Reliabel \\
2 & Intention to Use & $\mathbf{0 . 9 2 3}$ & Reliabel \\
3 & Perceived Usefulness & \\
\hline
\end{tabular}

Source: Data Processed, 2019
Table 3: R-square test

\begin{tabular}{ll} 
Attitude & R Square \\
Intention to Use & 0.770 \\
Perceived Usefulness & 0.750 \\
\multicolumn{1}{c}{ Source: Data Processed, 2019} \\
\hline
\end{tabular}

Table 3 can be checked whether the R-square estimation of the attitude variable is 0.770 . This can be deciphered that $77 \%$ of the changeability of the attitude build is clarified by the factors of intention to utilize and perceived usefulness while $23 \%$ of the frame of mind factors are clarified by factors outside the model.

Expectation to utilize variable have R-square $75 \%$ of changeability clarified by frame of mind and saw value while $25 \%$ of the goal to utilize factors are clarified by factors outside the model.

\subsection{Hypothesis Test}

The estimation of every parameter seen from its centrality worth shows data identified with the connection between the factors utilized in this examination. Testing the speculation in this investigation is to utilize or allude to the yield way coefficients esteems as appeared in table 4 underneath.

Table 4: Path Coefficients

\begin{tabular}{|c|c|c|c|}
\hline Variables & $\begin{array}{l}\text { Path } \\
\text { Coefficient: }\end{array}$ & $\begin{array}{l}\mathrm{T} \\
\text { statistics }\end{array}$ & Result \\
\hline $\begin{array}{l}\text { Perceived Usefulness } \\
(\mathbf{X}) \rightarrow \text { Intention to Use } \\
\text { (Y) }\end{array}$ & 0.368 & 3.094 & $\begin{array}{l}\text { Accept } \\
\text { ed }\end{array}$ \\
\hline $\begin{array}{l}\text { Perceived Usefulness X) } \\
\text {-> Attitude (M) }\end{array}$ & 0.877 & 27.638 & $\begin{array}{l}\text { Accept } \\
\text { ed }\end{array}$ \\
\hline $\begin{array}{l}\text { Attitude (M) } \\
\text { Intention to Use (Y) }\end{array}$ & 0.525 & 4.417 & $\begin{array}{l}\text { Accept } \\
\text { ed }\end{array}$ \\
\hline $\begin{array}{l}\text { Perceived Usefulness } \mathbf{X}) \\
->\quad \text { Attitude (M) } \\
\text { Intention to Use (Y) }\end{array}$ & 0.461 & 4.487 & $\begin{array}{l}\text { Accept } \\
\text { ed }\end{array}$ \\
\hline
\end{tabular}

Source: Data Processed, 2019

Speculation testing should be possible in t-measurements. For t-measurement test, on the off chance that the estimation of $\mathrm{t}$-insights $\geq \mathrm{t}$-table worth (1.96), at that point the examination theory is acknowledged. In light of table 4 over, the theory test above, it very well may be inferred that the theories H1, H2, $\mathrm{H} 3$ and $\mathrm{H} 4$ are acknowledged.

\section{DISCUSSION}


Ni Nyoman Sudiyani et al., International Journal of Advanced Trends in Computer Science and Engineering, 8(1.5), 2019,227 - 233

\subsection{The effect of perceived usefulness on intention to use}

$\mathrm{n}$ light of the aftereffect of speculation testing, it very well may be seen that perceived usefulness has positive and noteworthy impact to intention to utilize. It tends to be seen from the estimation of estimation parameter of saw handiness test to aim to utilize have positive connection worth equivalent to 0.368 and t-tally worth equivalent to 3.094 , while t-table worth equivalent to 1.96 . So it very well may be inferred that t-tally (3.094)> t-table (1.96). In this manner it very well may be presumed that perceived usefulness has a positive and huge effect on intention to use. Perceived usefulness affects aim to intention to use that if the higher the estimation of perceived value, it will build expectation to intention to use. The perceived usefulness worth impacts the expectation to intention to use of 0.368 . The principal speculation is acknowledged. This is predictable with research direct by Shanmugam et al [14] [15] [16] [17] [18] [19] [20] [21] [31].

\subsection{The effect of perceived usefulness on attitude}

In view of the criticalness level as delineated on the image above, it tends to be said that apparent helpfulness (27.638) impacts emphatically on attitude. Thus, it tends to be said that Hypothesis 2 which expresses that apparent handiness has positive impact on attitude is adequate. This outcome is like Shanmugam et al [14] [23] 25] [30].

\subsection{The effect of attitude on intention to use}

In light of the aftereffect of theory testing, it tends to be seen that attitude has positive and critical impact to intention to use. It very well may be seen from the estimation of estimation parameter of frame of mind test to expectation to utilize have positive connection worth equivalent to 0.525 and t-tally worth equivalent to 4.417 , while t-table worth equivalent to 1.96. So it very well may be presumed that t-check (4.417)> t-table (1.96). Consequently it very well may be reasoned that attitude has a positive and noteworthy effect on intention to use. Attitude impacts expectation ton intention to use that if the higher the estimation of demeanor esteem, it will build intention to use. The attitude worth impacts the aim to utilization of 0.525 . The third speculation is acknowledged. This is reliable with research lead by Shanmugam et al [14] [17] [24] [26] [33] [34].

\subsection{The effect of attitude on mediating perceived usefulness to intention to use}

In light of the essentialness level as portrayed on the image above, it very well may be said that perceived usefulness (4.487) influences intention to use with attitude as a mediating. Hence, it can be said that Hypothesis 4 which states that attitude has a mediating of perceived usefulness on intention to use. This result is similar to Shanmugam et al [14] [27] [28].

\section{CONCLUSION AND LIMITATIONS}

Based on the results obtained from this study, several conclusions can be delivered namely: 1) perceived usefulness of positive and significant to the intention to use e-money in Denpasar City, 2) perceived usefulness of positive and significant to the attitude of using electronic money in Denpasar City, 3) perceived usefulness of positive and significant to the desire to use e-money in Denpasar City, 4) the effect of perceived usefulness on the intention to use e-money in Denpasar City. In other words the commitment variable to bridge the relationship of perceived usefulness with the intention of use e-money in Denpasar City. However, due to the partial interaction, without the attitude, the perceived usefulness still have a positive and significant effect on the intention to use e-money in Denpasar.

The finishes of this investigation depend entirely on factual outcomes dependent on the idea of quantitative research. Maybe, top to bottom meetings with subjective research strategies are helpful to clarify further discoveries.

This examination just uses factors of perceived usefulness and attitude in evaluating intention to us e-money. Proposals for further research by including different factors that were not recently examined.

\section{REFERENCES}

1. Mishkin, F. The Economics of Money, Banking, and Financial Market (7th ed.). Pearson Addison Wesley. 2004.

2. Stewart, L. Technology Acceptance in Organizations Kansas: Kansas State University. 2013.

3. Fullenkamp, Connel and Saleh M. Nsouli.. Six Puzzles in Electronic Money and Banking. International Monetary Fund: IMF Institute. 2004.

4. Papadopoulos, G. Chapter 4: Electronic money and the possibility of a cashless society. Survey of Electronic Money Developments. 2007. https://doi.org/10.2139/ssrn.982781

5. Miller, R., Wolfgang, M., \& Barrie, S. The Future of Money. OECD PUBLICATIONS. 2002.

6. Hespeler, F. Electronic Money and the Monetary Transmission. 2008

7. Woda, Krzysztof. Money Laundering Techniques with Electronic Payment Systems. Information \& Security: An International Journal. 18, p.27-47. 2006. https://doi.org/10.11610/isij.1802

8. Athanassiou P., \& Natalia, M. G. Electronic Money Institutions Current Trends, Regulatory Issues and Future Prospects. European Central Bank publication. 2008.

9. Humphrey, D., Pulley, L., \& Vesala, J. Cash. Paper, and electronic payments: a cross-country analysis. Journal of Money, Credit, and Banking, 28(4), Part 2: Payment systems research and Public Policy Risk, Efficiency, and Innovation. 1996. https://doi.org/10.2307/2077928 
10. Mishkin, F. The Economics of Money, Banking, and Financial Market (8th ed.). Pearson Addison Wesley. 2008.

11. Jebran, K., \& Dipanker, A. Consumer's Perception on General Banking Activities of Commercial Banks: A Study in the Banking Context of Bangladesh. European Journal of Business and Management, 4(7). 2012.

12. Ozkan, S., Gayani, B., \& Ray, H. Facilitating the adoption of e-payment systems: theoretical constructs and empirical analysis. Journal of Enterprise Information Management, 23(3), p305-325. 2009.

https://doi.org/10.1108/17410391011036085

13. Miliani, Lani. Adoption Behavior of E-money Usage. Journal Information and Business Review, 5(7), p369-378. 2013.

14. Shanmugam, Arunagiri., Savarimuthu, Michael Thaz. and Wen, Teoh Chai. Factors Affecting Malaysian Behavioral Intention to Use Mobile Banking With Mediating Effects of Attitude, Academic Research International, 5(2), p236-253. 2014.

15. Kesharwani, Ankit and Bisht, S. S. The impact of trust and perceived risk on internet banking adoption in India. International Journal of Bank Marketing, 30(4), p303-322. 2011.

16. Raida, R. E. and Neji, B. The Adoption of the E-Banking: Validation of the Technology Acceptance Model. Journal Technology and Investment, 4, p197-203. 2013. https://doi.org/10.4236/ti.2013.43023

17. Mangin, J. P. L., Bourgault, N., Leon, J. A. M. and Guerrero, M. M. Testing Control, Innovation and Enjoy as External Variables to the Technology Acceptance Model in a North American French Banking Environment, International Business Research, 5(2), p13-26. 2012.

18. Sentosa, I., Soebyakto, B. B., Ming, C. W and Mat, N. K. N. A Structural Equation Modeling Of Internet Banking Usage In Malaysia. Journal of Arts, Science \& Commerce, 3(1), p75-86. 2012.

19. Farmani, Maryam., Kimiaee, Alireza And Fatollahzadeh, Farahnaz.. Investigation of Relationship between Ease of Use, Innovation Tendency, Perceived Usefulness and Intention to Use Technology: An Empirical study, Indian Journal of Science and Technology, 5(11), p3678-3682. 2012.

20. Chau, Vinh Sum and Liqing W. L. C Ngai. The youth market for internet banking services: perceptions, attitude and behavior. International Journal of Services Marketing, 24(3), p42-60. 2010. https://doi.org/10.1108/08876041011017880

21. Amini, M.T., Ahmadinejad, Mustafa and Azizi, M.J. Adoption of Internet Banking By Iranian. The International Journal of Management Science and
Information Technology, 1(1),p47-64. 2011.

22. Akturan, Ulun and Tezcan, Nuray. Mobile banking adoption of the youth market Perceptions and intentions, Marketing Intelligence \& Planning, 30(4), p444-459. 2012.

23. Abadi, H. R. D., Ranjbarian, B. and Zade, F. K. Investigate the Customers' Behavioral Intention to Use Mobile Banking Based on TPB, TAM and Perceived Risk (A Case Study in Meli Bank), International Journal of Academic Research in Business and Social Sciences, 2(10), p312-322. 2012.

24. Suki, Norayah Mohd and Suki, Norbayah Mohd. Exploring The Relationship Between Perceived Usefulness, Perceived Ease Of Use, Perceived Enjoyment, Attitude And Subscribers' Intention Towards Using 3G Mobile Services, Journal of Information Technology Management, 22(1), p1-7. 2011.

25. Mazhar, Fatima., Fiaz, Umar., Ishrat, Sobia., Razzaq, M.S and Khan, T.N. An Investigation of Factors Affecting Usage and Adoption of Internet \& Mobile Banking In Pakistan. International Journal of Accounting and Financial Reporting, 4(2), p478-501. 2014. https://doi.org/10.5296/ijafr.v4i2.6586

26. Juwaheer, T. D., Pudaruth, S. and Ramdin, P. Factors influencing the adoption of internet banking: a case study of commercial banks in Mauritius. World Journal of Science, Technology and Sustainable Development, 9(3), p204-234. 2012.

27. Hosseini, M.H., Fatemifar, A. and Masoumeh, R. Effective Factors Of The Adoption Of Mobile Banking Service By Costomers, Journal of Business Management, 4(6), p1-13. 2015.

28. Kanchanatanee, Kanokwan., Suwanno, Nuttida And Jarernvongrayab, Anu. Effects of Attitude toward Using, Perceived Usefulness, Perceived Ease of Use and Perceived Compatibility on Intention to Use E-Marketing, Journal of Management Research, 6 (3), p1-13. 2014. https://doi.org/10.5296/jmr.v6i3.5573

29. Ajili, Abdolazim., Salehi, Saeid., Moghaddam, Kurosh Rezaei., Hayati, Dariush and Karbalaee, Fereshteh. Estimating the Model of Investigating Attitude and Intention in the Usage of Variable Rate Irrigation Technology. American Journal of Experimental Agriculture, 2(3), p42-556. 2012.

30. Suki, Norazah Mohd and Ramayah.T. User Acceptance of the E-Government Services in Malaysia: Structural Equation Modelling Approach, Interdisciplinary Journal of Information, Knowledge, and Management, 5, p395-413. 2010.

31. Islam, Md. Zahidul., Low, Patrick Kim Cheng and Hasan, Ikramul. Intention to use advanced mobile phone services (AMPS), Management Decision, 51(4), p824-838. 2013. https://doi.org/10.1108/00251741311326590 
Ni Nyoman Sudiyani et al., International Journal of Advanced Trends in Computer Science and Engineering, 8(1.5), 2019,227 - 233

32. Hair, J.F., Anderson, R.E., Tatham, R.L. dan Black W.C. Multivariate Data Analysis 4th Edition. New Jersey: Prentice-Hall. 2010.

33. Lakshman K, N. Sulaiman. A study on Dynamics and challenges on Traditional Banking and E-Banking services among Senior citizen's at Bangalore City. International Journal of Advanced Trends in Computer Science and Engineering, 931935. 2019.

https://doi.org/10.30534/ijatcse/2019/91832019

34. T. Hariguna, \& Berlilana, "Understanding of Antecedents to Achieve Customer Trust and Customer Intention to Purchase E-Commerce in Social Media, an Empirical Assessment", International Journal of Electrical and Computer Engineering, 7(3), 1240-1245, 2017.

http://doi.org/10.11591/ijece.v7i3.pp1240-1245 